\title{
KTTS tiedepoliisina
}

Tätä kirjoitettaessa on kulunut kaksi kuukautta Korkeakoulu- ja tiedepoliittisen tutkimussäätiön, KTTS:n, aloittamasta operaatiosta Tandem-projektia vastaan. Se ei onnistunut aivan niin vaivattomasti ja elegantisti kuin KTTS:ssä ilmeisesti oli suunniteltu. Salamahyökkäys muuttui asemasodaksi. Ja vaikka Tandem-väittely ei ehtinytkään kovin laajaan julkisuuteen, osoittavat tieteellisen yhteisön sisällä ilmenneẹt reaktiot, että KTTS:n kaavailema helppo voitto ainakin osaksi muuttui moraaliseksi tappioksi. Niinpä esimerkiksi Mikko Juva esittää itsekritiikkiä säätiön operaatiosta. Hän totẹaa Suomen Kuvalehdessä $(1,1977)$ seuraavaa: "Julkistamistavassa tehtiin ilmeinen virhe. Ja säätiö saa syyttää itseään siitä, että keskustelu lähti hakoteille. ( . . . ) Säätiö on tähän asti minusta pysynyt puoluepolitiikan ulkopuolella, mutta valitettavasti täytyy myöntää, että tämä yksi toimenpide särkee kuvan. Nyt täytyy pitää erityinen huoli siitä, että vanha maine palaa."

Tapahtumat lienevät tuoreessa muistissa. Marraskuun alkuviikolla KTTS saattoi julkisuuteen suppean vihkosen nimeltä "Esimerkki tutkimuksen harharetkistä: arvioita Tandemin osatutkimuksesta Mainonta ja yhteiskunta”. Tällä 38-sivuisella vihkosella oli päätetty osoittaa, että Kaj Ilmosen ja Juha Partasen puolitoista vuotta sitten julkaisema Tandem-projektin osaraportti "Mainonta ja yhteiskunta" olisi "tutkimusskandaali". Tämän perusteella nostettiin esille väite,,$_{i}$ että tieteen ja tutkimuksen pääongelmana Suomessa olisi "valvonnan ja seurannan ongelma". Eikä vihkosessa todellakaan salata sitä, minkä tyyppisen tutkimuksen "valvontaa" peräänkuulutetaan, kohteena on "marxilainen tutkimusote". Vihkonen toimitettiin maan hallitukselle, ministeri Väänäsen erityiseen suojelukseen. Joukkotiedotusvälineissä julkaistiin KTTS:n toimittamia aineistoja ja sen johtohenkilöiden kirjoituksia tiedepolitikasta. KTTS:n operaation p o 1 i i tt is t a 1 u on net t a ei ole tarpeen erikseen osoittaa, sillä sen päivänpoliittinen tarkoituksenmukaisuus löi alusta saakka niin selvästi läpi. Tavoitteena oli Suomen Akatemian siirtäminen oikealle ja sensuurimielialan luominen marxilaista tiedettä ja tutkimusta vastaan, erityisenä kohteena Akatemian rahoittama painopistetutkimus yhteiskuntatieteiden alalla.

KTTS:stä ja Tandemista syntyi verratẹn laaja lehdistökeskustelu, jolle olivat luonteenomaisia pitkänä sarjana ilmestyneet eri professoreiden kannanotot. Mutta samalla käsittełyn piiriin tulivat laajemmatkin asiat: marxilaisen tieteen mahdollisuus, maan tiedepolitiikka ja koko tiedettä koskevan keskustelun ilmapiiri. Keskustelun kiistatta merkittävimpiä puheenvuoroja oli akateemikko G. H; von Wrightin kirjoitus Helsingin Sanomissa 24. 11. 1976. v: Wright asettui koko arvovallallaan tuomitsemaan KTTS:n operaation ja ennen kaikkea KTTS:n toimittaman vihkosen., "Kuinka kauan vielä voi vaitiollen kärsiä sitä hultttioitumista, joka on meneillään Suomen kulttuurielämässä ja tiẹteessä??". K@̣hta tämän jälkeen Helsingin Sạomat sulki mielipidesivunsa Tandem-väittelyḷ̆ä, ja keskustelu tyrehtyi myös 
muissa lehdissä.

Tutkijaliitto totesi liittokokouksessaan 20. 11. 1976 KTTS:n operaation loukkaavan tieteellisen keskustelun ja demokratian periaatteita. Liittokokous totesi KTTS:n operaation tähtäävän siihen, että "tieteelliseen maailmaan luotaisiin hallinnolliseen valvontaan perustuva tiedepoliisi".

KTTS ei ainoastaan aja tällaisen tiedepoliisin perustamista, vaan se on itse julistautunut tiedepoliisiksi. Tämän vuoden aikana on odotettavissa jatkoa. KTTS:llä on käynnissä "seurantatutkimus", jonka tarkoituksena on arvioida valtion yhteiskuntatieteellisen toimikunnan tutkimusrahoitusta vuosina 1971-1976. Loppuraportti ilmestyy kuluvan vuoden aikana. Tällöin tullaan epäilemättä esittämään täsmennettyjä poliisitoimia, joiden suunta ja luonne ovat arvattavissa Tandem-operaation ja KTTS:n muun toiminnan perusteella.

Mikä on KTTS ja mitä intressejä se edustaa? Lyhyesti sanottuna KTTS on monopolipääoman ja taantumusvoimien tiede- ja korkeakoulupoliittinen esikunta.

KTTS on perustettu 1972, reaktiona 1960-luvun lopun murrokselle maan yliopistoissa ja korkeakouluissa, demokraattisen liikkeen muodostumiselle ja etenemiselle tieteen, tutkimuksen ja korkeamman opetuksen instituutioissa. KTTS:n työvaliokunnan puheenjohtaja Pentti Laasonen totesi säätiön järjestämässä "Korkeakoulut ja tiedonvälitys" -seminaarissa keväällä 1975, että "säätiö on syntynyt (...) sen hätätilan puristuksessa. johon vuosikymmenen vaihteessa tunsimme koko korkeakouluoppilaitoksen ajautuneen". KTTS ei ole mitenkään puhtaasti kansallinen ilmiö. Aivan samantyyppinen järjestö sekä syntynsä että luonteenisa puolesta on Saksan Liittotasavallassa toimiva Tieteen vapauden liitto (Bund Freiheit der Wissenschaft). Tieteen vapauden liitto ajaa teollisuuden ja korkeakoulujen läheistä yhteistyötä, näkee päävihollisenaan kommunistisen ja demokraattisen liikkeen ja tukee aktiivisesti virkakieltojärjestelmää.

Suomen "tieteen vapauden liitto", KTTS, on toiminut näkývästi vasta vähän aikaa, ja Tandem-operaatio on sen toistaiseksi näkyvin toimenpide. KTTS on julkaissut erilaisia aineistoja ja järjestänyt seminaareja. Erityisesti KTTS on propagoinut monopolipääoman eri EEC-maissa ajamaa ns. jaksottaiskoulutusjärjestelmää. Vuodesta 1974 säätiö on osallistunut Kanava-aikakauslehden julkaisemiseen. Kanava-lehden profiili on selventävä KTTS:n luonteen ymmärtämisen kannalta: poliittista taantumusta" "puolueettoman asiantuntemuksen" hahmossa, "tieteen politisoitumisen" valittelua poliittisen oikeiston asemista. (Tyyli on tuttu. Kokoomuksen oikean laidan kulkijat Kullervo Rainio ja Erkki Pystynen hurskastelivat Helsingin Sanomissa 2. 12. 1976 Tandem-operaatiolla ihmetellen akateemikko v. Wrightin antautumista "puoluepolitiikà astaloksi"!)

KTTS onkin tähän mennessä valitettavastí kyennyt hankkimaan itsel- 
leen puolueettoman asiantuntijan julkisivua ja mikä pahinta myös tiettyä puolivirallista ja puolivaltiollist a asemaa, mikä on käynyt ilmi eräiden säätiön järjestämien seminaarien yhteydessä. Säätiö on kyennyt kokoamaan riveihinsä eräitä keskustalaisia professoreita, jotka eri yhteyksissä ovat tulleet tunnetuiksi demokraattisista kannanotoistaan, samoin kuin eräitä sosialidemokraattisia valtionvirkamiehiä. Mutta säätiön johtoelimet on kuitenkin miehitetty ennen kaikkea monopolipääoman edustajilla - Matti Virkkusesta alkaen -, valtion huippuvirkamiehillä, korkeakoulujen hallintomiehillä sekä edustavalla kokoelmalla taantumusprofessoreja. Ehdoton hegemonia säätiössä on monopolipääoman etujen ja ideologian ajajilla.

Sillä KTTS on niin hyvin a in e ellis e sti kuin a t t e ellisest i k i n monopolipääoman esikunta tiede- ja korkeakoulupolitiikan alalla. Toimintakertomuksensa mukaan KTTS rahoittaa toimintansa pääasiassa lahjoituksin, jotka vuonna 1975 olivat $414000 \mathrm{mk}$. Mistä nämä rahat tulevat, ei b̈le mikăään salaisuus. KTTS:n työvaliokunnan jäsen Pentti Viita toteaa Demarissa 2. 12. 1976 puolustellessaan osallistumistaan Tandemoperaatioon: "Tämä säätiö on elinkeinoelämän rahoittama." Tässä on säätiön aineellinen puoli; sen aatteellisen puolen olisi pitänyt tulla kaikille ajatteleville ihmisille selväksi viimeistään Tandem-operaation yhteydessä.

Liian vähän on julkisuudessa loppujen lopuksi kiinnitetty huomiota itse siihen vihkoseen, jonka varaan KTTS:n operaatio rakentui. Toivottavaa olisi, että mahdollisimman monet tieteellisen yhteisön jäsenet, opiskelijat ja myös työtätekevät lukisivat sen tarkkaan. Sillä harvoin on näin suurieleistä operaatiota toteutettu niin heikoin eväin. ."Esimerkki tutkimuksen harharetkistä" on liitteét poisluettuina 38 sivua pitkä kyhäelmä. Sen on laatinut Uuden Suomen toimituspäällikkö Jyrki Vesikansa, joka on kirjoittanut myös lyhyen tiivistelmän "asiantuntijalausunnoista". Asiantuntijalausuntoja - oikeammin: syyttäjän hankkimia todistajanlausuntoja - on kuusi, eivätkä ne kohoa häväistyskirjoituksen tasoa korkeammalle. Suurelta osalta nämä lausunnot ovat pelkkiä hilseitä, hätäisiä muistiinpanoja. Vesikansa ja KTTS nimeävät Ilmosen ja Partasen mainontatutkimuksen "skandaaliksi", mutta skandaali on aivan toisessa päässä, itse vihkonen on skandaali.

Jyrki V e s i k a n s a n osalle on siis langennut syyttäjän rooli. Hän sanoo Ilmosen ja Partasen tutkimuksessa olevan kyse "tietyn tutkimussuuntauksen kylläkin tähän asti räikeimmästä, mutta ei suinkaan ainutlaatuisesta tuotteesta". Vesikansa toteaa sallivasti, että marxilainen tutkimustapa on toki hyväksyttävissä eräänä tutkimusmetodina. Ja tämän jälkeen hän ryhtyy kumoamaan sitä, minkä juuri on sanonut. Hän asettaa kyseenalaiseksi, "kuinka laäjalti marxilaista metodia kannattaa kầyttää julkisin varoin rahoitetussa tutkimuksessa Suomessa". Painopistealojen tavoitetut- 
kimukseen marxilainen lähestymistapa soveltuu vain "harvinaisena poikkeuksena". Ja syy: "Painopisteajatteluun kuulunee loogisesti se, että tutkimuksessa käytetään yhteiskunnan kehittämistavoitteiden takia olemassaolevaan yhteiskuntajärjestelmään parhaiten soveltuvia metodeja." Näin siis itse demokratia työntää marxilaisen tieteen ja Suomen rajojen ulkopuolelle.

Vesikansa lyö monessa kohden mynttiä väitteellä, että Ilmonen ja Partanen edustavat kaiken lisäksi huonoa ja alkeellista marxilaista tutkimusta. He näet esittävät lähinnä kaikkien tiedossa olevaa "peruskurssitietoutta marxilaisesta talousteoriasta". Uuden Suomen viikonloppuliitteessä 26. 11. 1976 Vesikansa itse pakinoi taloudelliseen kasvuun vaikuttavista tekijöistä tähän tapaan: "Nyt osoitettiin, että tutkimus, tieto on taloudellisen kasvun tärkein tekijä. Toisin kuin esimerkiksi Karl Marx - hänen mukaansahan tuotąnnon tekijöitä ovat vain pääoma (koneet, vehkeet) sekä työ (nimenomaan lihastyö)." Vesikansan olisi ilmeisesti syytä toịmittaa itsensä marxilaisuuden peruskurssille tai ryhtyä lehteilemään Marxin "Pääomaa".

Kalevi Pi h a on kirjoittanut viitisen sivua, lähinnä tuoden esille, mitä Ilmosen ja Partasen hänen mielestään olisi pitänyt tutkia ja miten. Samalla hän ihmettelee Ilmosen ja Partasen käyttämää käsitteistöä, josta hän eräässä kohden sanoo, että sitä "tuon tuostakin saa tavata ymmärtämättä mitään”. Kommunikaatiokatkos näyttää todellakin olevan ylittämätön.

Erkki Pi h k la on kirjoittanut kolme sivua. Pihkala käyttää marxilaiseen tutkimukseen samaa argumentaatiota kuin Vesikansa. Toisaalta Ilmonen ja Partanen eivät tunne marxilaisuutta, toisaalta marxilaisuus ylipäänsä ei ole tieteellisesti pätevää! Pihkala kirjoittaa: "Marxilaisena teoreettisena tutkimuksena Ilmosen ja Partasen aikaansaannos (...$)$ jää missä tahansa marxilaisen poliittisen taloustieteen alkeisoppikirjassa esiintyvien teesien irvikuvaksi." Hän jatkaa kohta: "Eri asia taas on tämän marxilaisen teorian kestämättömyys sinänsä." Jääköön jälkimmäinẹn väittämnä tässä rauhaan, mutta mitä edelliseen tulee, niin Pihkala kirjoittaa poliittisen taloustieteen katsovan "vain materialistiset (sic!) hyödykkeet tuotannoksi". Tuntuu siltä, että Pihkala ei ole lukenut kunnolla "alkeisoppikirjoja" eikä ainakaan tutkimuksia, joissa juuri tästä kysymyksestä on paljon keskusteltu.

Matti Sä rkisilta on kirjoittanut yhden sivun, josta on vaikea sanoa mitään, koska siinäkään ei mitään sanota. Särkisilta pitää pahana, että "tutkimuksessa mainonnan suunnittelu ja toteuttaminen kollektivisoidaan kapitalismin tai monopolikapitalismin harjoittamaksi". Mikä tässä on pahasta? "Mainonta on länsimaisessa yhteiskunnassa konkreettinen, yritystason ilmiö." Todellakin, tällaisella argumentaatiolla julistetaan "tutkimusskandaaleja"!

Erkki T e i k a ri on kirjoittanut runsaat kaksi sivua tekstiä. Hän kirjoittaa pikakommentteja Ilmosen ja Partasen tutkimuksen joillekin sivuille, 
kommentteja, joiden tarkoitus, mieli ja merkitys jäävät peräti hämäriksi. Teikari pyrkii omien sanojensa mukaan tuomaan esille sellaisia kohtia, joissa ilmenee miten itse kohde Ilmosella ja Partasella unohtuu "silkan poliittisen julistuksen sivuun". Mitä ihmettä silloin esimerkiksi tämänkaltainen nootti osoittaa: "Ristiriitaista todistelua. Ensin annetaan tunnustus kapitalistiselle tuotannolle, mutta lopussa käytetään käsitteitä kummasti ristiin. Markkinoitavuus asetetaan käyttöarvon vastakohdaksi, vaikka jokainen tietää, kuinka ajan mittaan käy käyttöarvottomalle tuotteelle juuri markkinoiden vuoksi. Markkinoitavuuden tärkeä osakäsite on käyttöarvo, mikä tosin toisaalla esityksessä tunnustetaankin, mutta tämän sivun lopussa se on markkinoitavuuden rinnakkaiskäsite, jopa siis sen vastakohta." Teikari toteaa loppuhuipennuksessaan: "Olen sitä mieltä, ettei tämä teos ansaitse edes vastustetuksi tulemista." Tälle lähtökohdalle Teikari on ollut todella kuuliainen.

Henri V a r ti a is e n todistajanlausunto on kokoelman laajin, lähes kahdeksan sivua. Se muodostuu pääosin erilaisista pikakommenteista ja pikahuulista, joita Vartiainen on laatinut lähes joka toiselle Ilmosen ja Partasen tutkimuksen sivulle. Vartiaisen ideologia lyö tavan takaa läpi: "Sivulla 16 esitetään vanha väittämä työväestön riistosta (...) Sivulla 18 on Suomen osalta väärä käsitys pankkien hallitsemasta rahoituspääomasta (...) Työväenluokan aineellisen elintason kohottamismahdollisuudet ovat toteutuneet taloudelilisen kasvun eikä luokkataistelun kauttá; vain edellinen luo tähän tarvittavan vaurauden lisäyksen (...) Työväenluokka ei meillä enää pitkään aikaan ole kuulunut 'alistettuihin väestökerroksiin'." Vartiaisen teoreettisena lähtökohtana on marginalistinen talousteoria, jonka hän 'asettaa valmiina ja annettuna, ja koska Ilmonen ja Partanen eivät sitä käytä; ovat he epätieteellisiä. Näin yksinkertaista se on. Samalla Vartiainen osoittaa oman tietämyksensä asteen marxilaisesta arvoteoriasta. Hăn kirjoittaa: "Tavaran näyttöarvoa koskevassa luvussa (...) näyttäytyy kirjoittajien esittämän Marxin arvoteorian todellisuudelle vieraus. Kysyntää ei oteta huomioon." Ilmeisesti myös Vartiaisen olisi syytä ryhtyä lueskelemaan "alkeisóppikikirjoja".

Pentti V i it a, on runsaan sivun mittaisella lausunnollaan kirjoittanut itsensä Suomen tiedepolitiikan historiaan. Monissa demokraattisissa julkaisuissa on jo kiinnitetty huomiota Viidan älylliseen salto mortaleen: "Marxilaisen poliittisen taloustieteen soveltaminen suomalaiseen mainontaan on epämielekästä, koska Suomi on kapitalistinen maa." Eikä Viidan jatko ole sen parempaa: "Tutkijat asennoituvat suomalaiseen mainontaan kielteisesti siitä syysțä, että he asennoituvat suomalaiseen talousjärjestelmään kielteisesti. Ilmeisesti tutkijat asennoituisivat suomalaiseen mainontaan myönteisesti, jos Suomi olisi sosialistinen maa. Tutkimuksen tulokset ovat tämän vuoksi jo etukäteen määräytyneet kielteisiksi. Tulokset olivat näin jo etukäteen tiedossa." Jos Viidan sanat käännetään ympäri, saadaan todella yk- 
sinkertainen tiedepoliittinen ohjelma sille, millainen tutkimustyyli Suomessa on sallittavaa. Pitää vain suhtautua "myönteisesti" Suomen yhteiskunnan ilmiöihin. (Tosin tulokset ovat Viidan tarkoittamassa mielessä tällöinkin etukäteen tiedossa, mutta mitäpä siitä.)

Pelkkä häväistyskirjoitus tämä KTTS:n vihkonen on, ja sellaisena sitä on myös kohdeltava. Täysin kiistatonta on, että yhteiskuntatieteellinen tutkimus edellyttää ei ainoastaan tieteellistä vaan myös poliittista keskustelua, julkista ja avointa keskustelua. Mutta tästä ei ole kysymys KTTS:n vihkosen kohdalla; se on vain tieteen nimissä esitetty, taantumuksellisen demagogian läpitunkema häväistyskirjoitus, jonka avulla vaaditaan hallinnollisia toimenpiteitä ja väkivaltatoimia marxilaisia ja demokraattisia tutkijoita, demokraattisia ja työtätekevien etuja palvelevaa tutkimusta kohtaan.

Kysymys ei todellakaan ole ainoastaan t i e te e s tä Suomessa tai dem o k r a t i a s t a Suomessa. Kysymys on kummastakin.

KTTS ei pyri marxilaisen tutkimuksen kieltämiseen Suomessa suoraa vaan epäsuoraa tietä. Tämä juuri onkin demokratian kaventamisen pääreitti Suomessa: demokratian kaventaminen demokratian kulisseissa. Se näkyy meillä koko yhteiskuntaelämässä, tehtaissa ja virastoissa, tieteessä ja kulttuurissa.

Sen vuoksi eivät taantumusvoimat meillä suoraan erota kommunistisia ja demokraattisia tutkijoita, vaan pyrkivät kehittämään täydellișen syrjinnän järjestelmän. Marxilaista tutkimusta ei suoraan pyritä julistamaan laittomaksi, vaan siltä pyritään kiistämään legitimiteetti. Demokraattista tutkimusta vastaan ei huudeta avuksi poliisia, vaan pyritään perustamaan erityinen tiedepoliisi.

Sen, mitä on tapahtumassa, ovat panneet terävästi merkille sellaiset tie\demiehet ja demokraatit kuin Kettil Bruun, Yrjö Littunen, G. H. von! Wright ja heidän kaltaisensa. He eivät ole kommunisteja, mutta he ovat demokraatteja. Bruun viittasi jo vuosi sitten siihen, että Suomessa ollaan sytyttämässä McCarthy-tyyppisen noitavainon rovioita. v. Wright toteaa tuomitessaan johdonmukaisesti ja jyrkästi KTTS:n operaation: "Nämä ovat kovia sanoja. Tekee kipeää sanoa ne. Teen sen, koska aavistan ja pelkään, että nyt tapahtunut saa liikkeelle kulttuurivihamielisen mielipiteen vyöryn tuhoisin seurauksin ei vain tutkimuksen ehdoille vaan myös yhteiskuntamme koko ilmapiirille."

Tieteestä ja demokratiasta on kysymys. Yhä useammat tieteen ja tutkimuksen instituutioissa työskentelevät ovat tämän ymmärtämässä omakohtaisen kokemuksensa kautta. Totta on, että tieteen ja kulttuurin taantumus on uhkaamassa. Mutta totta on myös, että yhä useammat tieteen ja kulttuurin miehet ja naiset ovat tämän vaaran nähneet. 


\section{Tässä numerossa}

Tuure Lehén on poistunut luotamme. Hänellä oli suuri maine sekä maamme marxilaisten tutkijoiden että laajojen työläisjoukkojen keskuudessa. Julkaisemme joitakin arvioita Lehénin elämäntyöstä - $\mathrm{mm}$. Kommunistilehden pitkäaikaisen päätoimittajan Inkeri Lehtisen - sekä Lehénin panoksesta historiantutkimuksen, valtioteorian ja filosofian alalla.

Kysymys biologisen ja sosiaalisen välisestä suhteesta on viime aikoina ollut laajasti esillä sekä tieteen että julkisen keskustelun piirissä. Julkaisemme kaksi tähän ongelmapiiriin liittyvää artikkelia. Neuvostoliittolaisen A. D. Adon artikkelin aiheena on "ihmisen ekologia". Pekka Arinen käsittelee biologistisia selityksiä ihmistä ja yhteiskuntaa tutkivissa tieteissä.

Pekka Kosonen käsittelee probleemaa, josta nimenomaan marxilaisen tutkimuksen piirissä on viime vuosina keskusteltu paljon, nimittäin loogisen ja historiallisen suhdetta kapitalismin tutkimuksessa. Tämä kirjoitus liittyy Kososen laajaan esitykseen "Kapitalistisen yhteiskuntamuodon teo"íasta", joka on ilmestynyt Tutkijaliiton julkaisusarjassa. Vesa Oittisen artikkelin taustana puolestaan on se, että tänä vuonnà tulee kuluneeksi 300 vuotta Spinozan kuolemasta. Oittinen tutkii Spinozan materialismia ja esittää kunnianhimoisen teesin, että Spinozalla on historiallisen merkityksensä lisäksi myös ajankohtainen merkitys.

Dosentti Kettil Bruun, viime vuosien merkittävimpiä tiedepoliitikkoja ja demokraattisen tiedepolitiikan esitaistelijoita Suomessa, on varmasti lukijoillemme tuttu. Olemme haastatelleet Kettil Bruunia tiedepolitiikan viimeaikaisista piirteistä ja tendensseistä.

Pääkirjoitus käsitteli KTTS:n purkausta Ilmosen ja Partasen tutkimusta "Mainonta ja yhteiskunta vastaan". Mitä tämä kuuluisa moniste pitää sisällään, mihin se liittyy ja mitä se tuo esille? Pekka Sulkunen arvioi Ilmosen ja Partasen mainontatutkimusta.

Nobelin taloustieteen palkinnon myöntäminen Milton Friedmanille, arkkitaantumukselliselle monopolipääoman etujen ajajalle ja Chilen juntan neuvonantajalle, oli groteski ilveily. Julkaisemme Orlando Letelierin artikkelin "'Chigacon pojat' Chilessä", joka valottaa asioiden taustaa. Letelier toimi Allenden hallituksen suurlähettiläänä Washingtonissa. Pari viikkoa tämän artikkelin ilmestymisen jälkeen - 21. 9. 1976 - Letelier sai surmansa poliittisen salamurhan uhrina. 